\title{
Teologi Pembebasan Ali Syari'ati (Kajian Humanisme dalam Islam)
}

\author{
Siti Syamsiyatul Ummah \\ UIN Sunan Kalijaga Yogyakarta \\ zenjafa.keai@gmail.com
}

\begin{abstract}
As one of the most prominent Muslim thinkers of modern times, Ali Syari 'ati's role in resisting the repression of Pablevi's regime is undeniable. He presented bimself as a propagandist gusting the spirit of youth in Iran in the 1970's to rise up and resist the authoritarian and oppressive regime of Pablevi. Ali Syari 'ati had succeeded in building a revolutionary islamic ideology on the foundations of taubid to elevate degrees and support egalitarianism in bumans. In the view of Ali Syari' ati, taubid is a oneness between god, buman, and the universe. Therefore, any form of social discrimination, injustice, depotism, and persecution must be opposed because it is separate from the rivals of taubid. It's a library research which deals with liberation theological thinking in the perspective of Ali Syari 'ati in lifting and figbting for emancipation, responsibility and buman freedom. The subject of this post is the biography of Ali Syari 'ati, the views of the taubid world: the taubid is the free previens of Ali Syari' ati, the religious bumanistic concept Ali Syari'ati, and the taubid scheme of thought in the religious bumanistic concept of Ali Syari'ati.
\end{abstract}

Keyword: Ali Syari 'ati, Liberation Theology, Islamic Humanism

Abstrak. Sebagai salah satu pemikir Muslim terkemuka di zaman modern, peran Ali Syari'ati dalam melawan penindasan rezim Pahlevi tidak dapat dimungkiri lagi kebenarannya. Ia tampil sebagai propagandis yang membakar semangat kaum muda di Iran pada 1970-an untuk bangkit dan melawan rezim Syah Pahlevi yang otoriter dan menindas. Ali Syari'ati berhasil membangun ideologi Islam yang revolusioner dengan fondasi tauhid untuk mengangkat derajat dan menyokong egalitarianisme (persamaan) pada manusia. Dalam pandangan Ali Syari'ati, tauhid adalah kesatuan antara Tuhan, manusia, dan alam semesta. Maka, segala bentuk diskriminasi sosial, ketidakadilan, kedzaliman, dan penindasan harus dilawan karena termasuk hal yang syirik (lawan tauhid). Tulisan ini merupakan library research yang membahas tentang pemikiran teologi pembebasan dalam prespektif Ali Syari'ati dalam mengangkat dan memperjuangkan emansipasi, tanggung jawab dan kebebasan manusia. Sub pembahasan dalam tulisan ini adalah biografi Ali Syari'ati, pandangan dunia tauhid: Tauhid yang membebaskan prespektif Ali Syariati, konsep religius humanistik Ali Syari'ati, serta skema pemikiran tauhid dalam konsep religius humanistik Ali Syari'ati.

Kata kunci: Ali Syari’ati, Teologi Pembebasan, Humanisme Islam. 


\section{PENDAHULUAN}

Dewasa ini, kesulitan untuk menemukan titik temu di mana tauhid dikaitkan dengan pembebasan merupakan salah satu hal yang masih banyak dialami di antara kita. Diantaranya mungkin disebabkan oleh situasi di mana kita telah dikondisikan untuk memiliki tingkat kepercayaan yang terbatas pada taqlid (penerimaan buta), ritual, ibadah keagamaan, dan dogma teologis. Iman (keyakinan) kita seperti jubah di masjid. Sehingga, Islam dengan tauhid sebagai fondasi ajarannya menjadi kurang bermanfaat bagi umat manusia, apalagi berkah karena Islam sering digunakan sebagai pembenaran untuk melanjutkan ketidakadilan (hal yang sebenarnya paling ditentang dalam Islam).

Rekonstruksi teologi Islam adalah masalah yang sangat mendesak dalam konteks peningkatan kondisi umat Islam untuk mencapai negara yang lebih baik. Teologi Islam dengan nada yang lebih membebaskan adalah semacam teologi yang dibutuhkan untuk memperbaiki situasi umat Islam saat ini yang tertinggal dan jatuh dalam keterbelakangan dibandingkan dengan penganut agama lain. Untuk membangun format kerangka teologi pembebasan inilah dibutuhkan sebuah interpretasi baru yang rasional dan ilmiah untuk mempertahankan referensi doctrinal pada teks-teks suci (alQur'an dan Hadits) dalam merumuskan kerangka kerja teologi konstruktif bagi umat Islam (Adhan, 2016: 259-261).

Menurut Toshio Kuroda sebagaimana dikutip oleh Syamsul (2016: 259-261), dalam menyusun konstruksi teologis yang relevan untuk mengatasi pelbagai masalah yang muncul dalam kehidupan manusia didasarkan pada kepercayaan yang menjunjung tinggi Islam sebagai norma kehidupan yang sempurna dan akomodatif yang dapat disesuaikan untuk setiap bangsa dan setiap waktu. Wahyu Tuhan yang sifatnya abadi dan universal, terdiri dari semua jenis kegiatan dari seluruh aspek peristiwa humanistik tanpa perbedaan antara pencarian material (dunia) dan immaterial (spiritual). 
Mengacu pada pernyataan Toshio Kuroda tersebut, dapat disimpulkan bahwa ruang lingkup Islam mencakup segala aspek, mulai dari kehidupan duniawi, mental, serta Ketuhanan. Dengan demikian teologi (tauhid) memiliki fungsi vital dalam pemikiran umat Islam, institusi sosial politik Islam, dan dalam peradaban. Tauhid harus menanggung makna integrasi atau persatuan antara dimensi transenden (spiritual) dan imanen (sosial). Tidak ada pemisahan yang ketat antara realitas ilahiyah yang transenden dan realitas alam dan manusia yang imanen untuk menetapkan posisi yang biner. Dalam pandangan Murtada Motahhari, konstruksi teologi pada akhirnya akan menjadi pandangan dunia tentang tauhid yang uni-polar dan uni-aksial (Dabashi, 1987: 103).

Selama ini kita hanya mengenal dua paradigma teologi yang masih berlaku di dunia Islam, yakni paradigma Asy'ariyah dan Salafiyah. Paradigma Asy'ariyah lebih banyak penganutnya daripada paradigma Salafiyah. Sementara keduanya (paradigma Asy'ariyah dan Salafiyah) saling berebut pengaruh, hal ini yang kemudian memunculkan paradigma kritis Ali Shari'ati dan Asghar Ali Engineer yang menginginkan adanya paradigma baru dalam teologi yang tujuannya untuk membela masyarakat yang tertindas. Paradigma ini menggagas sebuah paradigma teologi yang lebih memihak kaum papa, yang kemudian dikenal dengan teologi pembebasan (Ahmad, 2011: 52).

Ali Syari'ati adalah salah satu Pemikir Muslim terkemuka di zaman modern yang peduli akan tema pembebasan dari agama. Melalui pandangannya yang sintetik, yaitu pandangan dunia berbasis tauhid, dia menonjol sebagai propagandis yang membakar semangat kaum muda di Iran pada 1970-an untuk bangkit melawan penindasan rezim Pahlevi. Kebenarannya sebagai salah satu tokoh terkemuka dalam teologi pembebasan Islam tidak dapat disangkal. Ia bahkan menawarkan hidupnya sendiri untuk misi tersebut (Adhan, 2016: 262). Pemikirannya mewakili kelompok intelektual non-ulama, dengan ciri pemikiran yaitu kritisisme yang dibangun 
di atas ideologi revolusioner Barat yang telah dicangkokkan ke dalam teologi Syi'ah (Anjar, 2014: 191). Tujuan utama Ali Syari'ati adalah untuk memberi keyakinan bahwa Islam yang "benar" itu sebenarnya ideologi paling revolusioner yang bisa disimpulkan manusia modern (Dabashi, 1987: 103).

Menurut Syari'ati, Islam pembebasan adalah Islam yang diwarisi oleh Imam Husain. Kemartirannya di Karbala adalah sumber inspirasi bagi Sang tertindas untuk melestarikan Islam yang otentik. Islam seperti itu adalah yang paling awal Islam Shi'a. Bagi Syari'ati, Islam sejati adalah revolusioner, dan Syiah sejati adalah revolusioner Islam (Nugroho, 2017: 255-256). Ia menghendaki agama (Islam) sebagai dasar dari nilai kemanusiaan yang sejati (Nurrochman, 2014: 54).

Konsep kesyahidan sebagai gagasan untuk bangkit dan bersaksi telah menjadi bagian integral dari ideologi Islam. Setiap orang dapat memandangnya sebagai sebuah ritus (tata cara keagamaan) yang menggerakkan para penghayat seni yang hidup secara individual untuk menjelma menjadi sosok yang direstui Al Husain, sebab "sosok Al Husain”, sebagaimana diungkapkan Ali Syari'ati, semata-mata hanya milik Al husain itu sendiri (Syari’ati, 2011: 6).

Sebagai seorang intelektual modern yang tumbuh dalam keluarga ulama progresif, Ali Syari'ati mengemukakan teori-teori Marxis tentang perjuangan kelas, eksploitasi kapitalis dan imperialisme dalam kerangka keagamaan, membangun Teologi Pembebasan Muslim yang membuatnya bermusuhan dengan ulama konservatif dan menyebabkan pemerintah Iran memenjarakannya (Cole, 1984: 157-158). Ia adalah seorang pemikir besar yang memicu energi intelektual untuk Revolusi Islam di Iran yang oleh Ali Rahnema, seorang Professor di Prancis, Ali Syari'ati disebut mungkin sebagai satu-satunya intelektual Iran abad ke-20 yang menciptakan momentum sosialpolitik yang melahirkan gerakan sosial, yang memuncak dalam revolusi" (Afrasiabi, 2000: 140). 
Berdasarkan wacana pemikiran di atas, jelaslah bahwa Ali Syari'ati mempunyai pemikiran keislaman yang revolusioner, yang berbeda dengan pemikir Islam mainstream. Segmen pemikiran ini yang disebut banyak pihak menjadi faktor penting yang mampu menggugah pemikiran para kaum muda Iran yang berorientasi Islam untuk bangkit melawan rezim Syah. Ia menginginkan sebuah peradaban Islam yang hendak dibangunnya yang didasari oleh gerakan-gerakan yang diikutinya sejak gerakan revolusi sampai kematiannya, yang kemudian didasari oleh prinsip-prinsip dari Islam (Irdayanti, 2018: 8). Lewat aksi intelektualnya, Ali Syari'ati telah membuktikan kepada dunia bahwa Islam tidaklah reaksioner, pasif, dan status quo. Islam mampu menggerakkan menggerakkan manusia untuk melawan berhalaberhala peradaban (Supriyadi, 2010: T.h.).

Sebagai salah satu pemikir Islam yang menaruh perhatian lebih kepada humanisme dari ide dan gagasan yang ditawarkannya, pemikiran Syari'ati selalu menarik untuk dikaji. Dengan semangat tauhid, Ia mengajak manusia menuju pada egalitarianisme (persamaan) dan memperjuangkan pembebasan pada manusia dan membangun kesadaran akan perannya sebagai khalifah Allah di muka bumi.

\section{PEMBAHASAN}

\section{Biografi Ali Syariati}

Ali Syari'ti, yang pada waktu kecil bernama Muhammad Ali Mazinani, lahir 23 Nopember 1933 di desa Mazinan, pinggiran kota Masyhad dan Sabzavar, propinsi Khorasan Iran. Guru pertama kalinya adalah ayahnya sendiri (Muhammad Taqi Syari'ati). Pada awal 1940-an, ayah Ali Mazinani mendirikan usaha penerbitan bernama "Pusat Penyebaran Kebenaran Islam" (The Center for Propagation of Islamic Truths) di Mashhad, Provinsi Khurasan. Lembaga ini bertujuan untuk mengkampanyekan Islam sebagai agama yang sarat dengan kewajiban dan komitmen sosial (Tobroni, 2015: 243). Ibunya berasal dari kelas tuan tanah kecil-kecilan (Syari'ati, 2017: 5) 
Ayahnya adalah adalah seorang sarjana agama terkenal dari ketenaran nasional dan seorang ahli penafsiran Al-Quran (Mehbi Abedi dan Mehdi Abedi, 1986: 229). Ia kemudian menjadi seorang ulama yang berpikiran reforma yang telah menanggalkan pakaian ulama dan mencari nafkah dengan mengelola ruang kuliah agamanya sendiri dan dengan mengajar tulisan suci di sebuah sekolah menengah setempat. Karena ia secara terbuka menganjurkan reformasi, 'ulama' konservatif menamakannya Sunni, Baha'i, dan bahkan seorang Wahhabi. Beberapa tahun kemudian Ali Syari'ati dengan bangga menyatakan bahwa ayahnya, lebih dari siapa pun, telah memengaruhi perkembangan intelektualnya (Abrahamian, 1982: 24-25).

Periode 1950-1951, Ali Mazinani bersama ayahnya, bergabung dalam Gerakan Penyembah Tuhan Sosialis dan mengikuti gerakan nasionalisme yang dipimpin oleh Perdana Menteri Muhammad Mushadiq. Gerakan ini mencapai puncaknya dengan menjadi Liga Kemerdekaan Rakyat Iran tahun 1953. Gerakan ini bertujuan melancarkan kudeta melawan Rezim Syah Reza Pahlevi pada tahun 1953. Akan tetapi, gerakan ini gagal dan sebagai konsekuensinya Ali bersama ayahnya dipenjara di rumah tahanan Qazil Qala'ah, Teheran selama 8 bulan.

Setelah bebas, tahun 1956, Ali Mazinani melanjutkan studi di Fakultas Sastra Universitas Masyhad. Tahun 1960, ia mendapat beasiswa dari pemerintah Iran dan melanjutkan pendidikan di Universitas Sorbonne, Perancis. Di Sorbonne inilah, ia menimba banyak ilmu kepada para intelektual terkemuka seperti Louis Massiggnon (Islamolog Prancis beragama Katolik), Jean-Paul sartre, “Che” Guevara, Jacques Berque, Henri Bergson dan Albert Camus (Tobroni, 2015: 243).

Pada tahun 1965, Ali Kembali ke Iran setelah menamatkan pendidikannya. Akan tetapi, ia ditangkap di Bazarqan (perbatasan Iran-Turki) dan dipenjara 1,5 bulan. Ia dituduh berpartisipasi dalam aktifitas politik ketika sedang belajar di Perancis. Periode 1967-1973 adalah periode paling aktif 
dalam hidup Ali pasca pembebasan dari hukuman penjara yang kedua. Kemudian ia mengajar di Masyhad, Hussainiyah Irshad di Teheran, serta beberapa universitas dan lembaga pendidikan Islam lainnya. Dalam waktu singkat, ia menjadi populer dengan aktifitasnya yang selalu mempropagandakan perlawanan terhadap Syah Pahlevi.

Akhirnya setelah ayah Ali ditangkap, pada September 1973, Ali Mazinani menyerahkan diri pada polisi rahasia Shavak dan ia diganjar hukuman 18 bulan penjara. Karena desakan masyarakat Iran dan juga protes dari dunia internasional, pada 20 Maret 1975 Ali Mazinani terpaksa dibebaskan. Namun, ia kemudian diawasi dengan ketat, dilarang menerbitkan buku, dan dilarang berhubungan dengan murid-muridnya (Tobroni, 2015: 243-244).

16 Mei 1977 Muhammad Ali Mazinani mengganti namanya menjadi Ali Syari'ati dan meninggalkan Iran. Pergantian nama ini dimaksudkan agar ia tidak terdeteksi pihak bandara dan polisi Iran (SAVAK). Lama tidak terlihat, pada 8 Juni 1977 SAVAK mengeluarkan edaran bahwa Ali Mazinani telah meninggalkan Iran secara illegal dengan mengganti nama menjadi Ali Syari'ati. Pada 19 Juni 1977, Syari'ati ditemukan tewas di Southampton, Inggris. Pemerintah Iran menyatakan Syari'ati tewas akibat penyakit jantung, tetapi banyak yang percaya ia dibunuh oleh Polisi rahasia Iran.

Ali Syari'ati memang tidak sempat menyaksikan kejatuhan Shah Reza. Namun, pemikirannya tetap diakui sebagai salah satu inspirator revolusi tersebut. Sebagaimana diungkap John L. Esposito, bahwa posisi Khomeini dalam Revolusi Islam Iran lebih berperan sebagai pemimpin revolusi, sedangkan perumus dan penyedia ideologi revolusinya sendiri adalah Ali Syari'ati._Secara sederhana, ada dua kubu yang menjadi pilar Revolusi Islam Iran, yaitu: religius tradisional Syi'ah (diusung oleh para ulama atau mullah) dan semi-religius yang tetap berbasis Syi'ah (tetapi dibawa oleh para intelektual berlatar pendidikan sekuler). Yang pertama diwakili Ayatullah 
Ruhullah Musawi Khomeini dan Ayatullah Murtadha Muthahhari. Yang kedua diwakili Ali Syari'ati, Mehdi Bazargan, dan Bani Sadr (Tobroni, 2015: 244).

\section{Pandangan Dunia Tauhid: Tauhid yang Membebaskan prespektif Ali Syari'ati}

Sebagai dasar utama dalam pemikirannya yang berakar dari tauhid maka Syariati berpendapat bahwa segala sesuatu harus dilihat dan dipahami dari perspektif keyakinan Tauhid. Yaitu, "memandang seluruh alam semesta sebagai satu kesatuan". Menurutnya, tidak ada pembagian dalam alam semesta antara dunia dan akhirat, alamiah dan sura alamiah, maupun antara substansi dan esensi, karena kesemua nya adalah satu. Yaitu, sebagai sebuah organisme tunggal, sedangkan dunia ini dipandang sebagai emporium tunggal. Hal ini kontras dengan syirik yang memahami dunia serba terbagi, kontradiksi, kacau dan melihat dunia sebagai sebuah sistem feudal (Sari, 2018: 197). Dengan kata lain pandangan dunia Tauhid dalam pandangan Syari'ati adalah pandangan dunia yang melihat kenyataan sebagai realitas yang holistik, universal, integral dan monistik (Syari'ati, 1992: 222-223).

Pandangan hidup yang seperti ini yang kemudian oleh Syariati dianggap mampu membantu manusia meraih kesadaran agamanya dan membangunkan manusia untuk melaksanakan tugas dan fungsinya sebagai wakil Allah yang memiliki kebebasan untuk menentukan nasibnya sendiri dan nasib seluruh umat manusia di muka bumi serta memulihkan makna spiritual bagi alam. Dalam keyakinan tentang keesaan Allah, manusia dan alam itu eksis, dalam artian memiliki makna, tujuan dan kesadaran diri."

Lebih daripada itu, Syari'ati juga menjelaskan bahwa pada hakikatnya, segala sesuatu terdiri dari dua kategori besar yaitu, ghaib dan dzahir. Akan tetapi menurutnya, hal ini bukanlah sebuah bentuk dualisme. Adanya dikotomi antara sesuatu yang ghaib dan dzahir merupakan sebuah klasifikasi nisbi yang didasarkan pada keadaan dan daya kognitif manusia. Bagian yang 
ghaib tidak bisa dijangkau oleh riset, pengamatan dan eksperimen. Sedangkan yang dapat dijangkau oleh ilmu pengetahuan melalui risetnya adalah sesuatu yang dzahir, ayat-ayat kauniyah. Cara dan pendekatan Al-Quran terhadap ayat-ayat kauniyah inilah yang kemudian menurutnya sangat relevan dengan perkembangan ilmu pengetahuan modern. Dalam hal ini, mengacu pada rumusan Syariati sendiri bahwa, "Dalam bahasa al-Quran, "Tauhid” (keesaan) memberkati manusia dengan "kebijakan" dan "kebenaran" (Sari, 2018: 197198).

\section{Konsep Religius Humanistik Ali Syari'ati}

Sebagai seorang pemikir bebas yang terus melakukan pencarian kebenaran dalam hidupnya melalui mistik, pemahaman intuitif tentang dunia serta peran Tuhan dalam segala lingkup kehidupan maka tidak heran jika kemudian dalam pandangannya, Syari'ati kerap menunjukkan kepekaan yang paradoksal. Dia tampil ditengah publik untuk mempromosikan aksi revolusi kolektif guna memperjuangkan keadilan sosial dan kebebasan dari ketertindasan. Diantara ciri dari pemikirannya adalah bahwa agama harus ditransformasikan dari hanya sebatas ajaran etika pribadi menjadi suatu program revolusioner untuk mengubah dunia. Dalam konteks ini, dia menyerupai Ayatullah Ruhullah Al-Musawi Khomeini (1902-1089), yang senantiasa menolak gagasan bahwa Islam itu hanya merupakan persoalan hukum dan ritual yang mengatur hal-hal teknis seperti wudhu, menstruasi, kelahiran, makanan, dan sejenisnya (Saleh, 2018: 186).

Pilihannya akan pandangan dunia religius (pamdangan dunia integralis) yang menggabungkan Tuhan, manusia dan alam semesta di tengah dominasi pandangan dunia yang materialistik sekarang ini merupakan penawaran Syari'ati dari gagasannya yang bersumber dari tauhid. Jenis pandangan dunia ini ialah yakin bahwa jagat raya adalah sesuatu yang datang dari Tuhan, yang sadar dan responsif terhadap tuntutan-tuntutan spiritual serta aspirasi manusia. Hanya saja, kerangka dasar pandangan dunia yang 
bersifat religius yang dimaksud adalah cara pandang yang berbasis pada hasil riset ilmiah yang bersifat saintifik bukan bentuk yang ortodoks atau ekstrim. Ali Syari'ati mengambil pilihan pandangan hidup sintetik di antara kutub ekstrim di atas yaitu pandangan hidup religius humanistik yang mensublimasi unsur manusia sebagai makhluk yang progresif, selalu mencari kesempurnaan dan sangat manusiawi (Sabara, 2016: 220-221).

Syari’ati memperkenalkan manusia sebagai makhluk dua dimensi yang terdiri dari tubuh dan jiwa yang dalam hal ini ia pandangannya mengikuti pada kisah terkenal dalam al-Qur'an. Ia menggambarkan manusia sebagai makhluk yang terbuat dari tanah liat dengan Roh milik Allah yang dihembuskan napas padanya. Karena itu manusia adalah dikotomi tubuh dan roh, materi dan spiritual (Vakily, 1991: 68).

Dia tidak menyelesaikan ketegangan antara manusia karena di satu sisi entitas yang tidak dapat dipisahkan dari esensi yang menyatu yang terdiri dari Tuhan, manusia dan alam. Di sisi lain, manusia juga sebagai makhluk otonom. Adalah fakta bahwa setelah mencurahkan banyak upaya intelektual untuk meyakinkan para pendengarnya bahwa unsur-unsur itu menyatu, Syari'ati kemudian menegaskan pemisahan mereka. Tiga elemen terpisah satu sama lain tetapi sumbernya sama. Kesemuanya memiliki satu arah dan bergerak serta hidup dengan satu kehendak dan semangat. Dengan keras Syari'ati menolak gagasan tentang kontradiksi yang memengaruhi kesatuan Allah, manusia dan alam. Definisi Tauhid menghindari antinomi, karena menurutnya kesatuan integral tidak mungkin hancur (Akhavi, 1988: 405-406).

Gagasan yang ditawarkannya tentang pandangan tentang dunia yang religius bumanistik tidak lain adalah untuk memerangi bentuk dualisme kelas yaitu, kelas penguasa dan yang dikuasai, dan kelas borjuasi dan proletariat. Sehingga manusia akan menemukan keesaan yang orisinil yang diharapkan dapat membangun kesadaran dalam dirinya akan misi dan perannya sebagai khalifah Allah di muka bumi. Karena menurutnya, manusia adalah makhluk 
merdeka dan memiliki potensialitas tanpa batas untuk menentukan nasibnya sendiri bukan ditentukan oleh kekuatan eksternal yaitu, dengan membangun semangat Tauhid (Sabara, 2016: 220-221).

Dengan menjelaskan proses pencarian jiwa dan pencapaian kebenaran, Ali Syari'ati menggambarkan pencariannya terhadap kesempurnaan tujuan semua sufi. Sebagai seorang spiritualis, ia tidak sertamerta juga larut dalam keasyikan spiritual dan abai terhadap dunianya. Ia meyakini bahwa spiritualitas hendaklah berbanding lurus dengan pencerahan dan pembebasan. Spiritualis sejati adalah seperti sosok imam Ali dan Imam Husein yang tampil sebagai agen yang memperjuangkan pembebasan umat. Sosok Syariati yang spiritualis-humanis ini tampak pada pemikirannya mengenai haji. Dalam pandangannya, haji merupakan sebuah ritual yang membawa umat Muslim pada sebuah refleksi evolusi eksistensial dan setiap ritus haji mengantarkan manusia pada makna pembebasan yang sesungguhnya (Sabara, 2016: 217).

Perhatiannya yang lebih pada humanisme seolah-olah ia merupakan "agama baru" bagi masyarakat barat, terutama di Eropa dewasa ini. Namun dengan tajam Syari'ati mengkritik apa yang dikemukakan oleh orang-orang Barat mengenai humanisme, sementara dalam kenyataannya mereka cenderung untuk menghancurkan (dehumanisasi). Menurutnya, terdapat empat pengertian mengenai humanisme yang dikenal selama ini. Pertama, humanisme menurut pengertian liberalisme Barat. Kedua, humanisme menurut pengertian Marxisme. Ketiga, humanisme eksistensialis. Dan Keempat, humanisme agama (humanisme Islam).

Dalam Islam, humanisme merupakan kumpulan nilai-nilai Ilahi dalam diri manusia yang membentuk moral dan warisan budaya religiusnya. Pada konsep tauhid Islam, manusia dipandang sebagai makhluk yang bertentangan yang memiliki esensi ganda dari tanah liat dan roh ilahi, dari debu dan Tuhan, serta keinginan untuk memilih satu dari yang lain. Oleh karena itu, pertama, 
dalam Islam manusia memiliki kemuliaan bukan dengan caranya sendiri tetapi hanya dalam hubungannya dengan Tuhan (Allah); kedua, manusia memiliki takdir; ketiga, manusia punya pilihan. Kepemilikan pilihan inilah yang kemudian memberi manusia tanggung jawab untuk mengangkat dirinya dari menjadi debu menuju penyatuan dengan Allah (konsep ini sangat mirip dengan konsep Hegelian tentang gagasan absolut yang berevolusi dari ketiadaan menjadi segala sesuatu).

Tanggung jawab atau mastuliat oleh Syari'ati dipandang sebagai konsep yang sangat kritis karena ia cenderung memperluas implikasinya dari ranah filsafat dan teologi menjadi bidang politik. Dengan demikian, secara implisit Syari'ati menyerukan kepada massa Dunia Ketiga secara umum dan umat Islam pada khususnya, untuk mengangkat diri mereka dari penawanan menjadi khalifah Allah di bumi, untuk pembebasan. (Pendekatan ini juga mirip dengan metafora Hegelian Marx tentang perkembangan kelas dari "di dalam dirinya sendiri" menjadi "untuk dirinya sendiri") (Bayat and تايب فصاً, 1990: 5).

Kebebasan dan penguasaan manusia atas alam mencapai suatu titik sehingga cenderung mengakibatkan hancurnya kemanusiaan (dehumanisasi). Hidup manusia akhirnya terperangkap pada hasil penguasaan alam dan ilmu serta teknologi yang dihasilkannya. Manusia dilihat hanya sebagai salah satu faktor produksi, sementara ia terjebak pada sistem yang tidak manusiawi. Manusia menjadi budak mesin ciptaannya sendiri. Disinilah tokoh-tokoh eksistensialis meneriakkan jeritan mereka agar manusia menyadari eksistensi dirinya sebagai manusia, bukan hanya robot-robot yang dikendalikan oleh sistem yang membelenggu kebebasan manusia.

Humanisme agama lebih menitikberatkan pandangannya pada falsafah penciptaan. Manusia diciptakan oleh Tuhan dan oleh karena itu ia mempunyai hubungan yang unik dengan Tuhannya. Manusia dari perspektif religius ini dapat juga dibedakan antara yang menganggap ketinggian harkat 
dan nilai manusia, disamping ada yang mencerminkan kerendahan derajat manusia (Ramadhan, 2011).

Dari beberapa sudut pandang mengenai manusia dan kemanusiaan kemudian dapat ditarik beberapa aspek bahwa bagi para humanis, manusia dipandang dalam perspektif yang cukup komplek diantaranya, manusia dapat dilihat sebagai makhluk tertinggi dan independent, kreatif, idealistis, bermoral serta sebagai makhluk yang sadar yang mampu menyadari dirinya.

Manusia yang oleh Syari'ati dilihat sebagai wakil-wakil Allah sekaligus keluarga-Nya dengan menyebutkan fakta bahwa al-Quran dibuka dengan nama Allah dan diakhiri dengan nama rakyat (an-nas). Kakbah, sebagai kiblat umat Islam disebut sebagai rumah Allah bukanlah dimaksudkan Allah butuh atau mempunyai rumah melainkan rumah itu adalah milik semua orang (rakyat) dan Makah disebut pula al-bayt al-'atiq yang artinya adalah kebebasan.

Penyamaan an-Nas dengan Allah yang dimaksud di sini hanya dalam wacana sosial bukan dalam konteks aqidah. Dalam ranah teologis, antara Allah dengan manusia ( $A n-N a s)$ tetapi dalam ranah sosiologis, menurut Syariati, keduanya adalah sinonim. Siapapun bisa tidak sepakat, namun inilah sumbangsih pemikiran Syariati yang mampu menerjemahkan kosa kata agama dalam kosa kata sosiologis (Ramadhan, 2011).

Syariati melihat adanya integralisme atau kesatuan pola pikir yang diperlihatkan seseorang yang memiliki mazhab pemikiran. Kesatuan, keterpaduan dan harmonisasi pemikiran seseorang yang memiliki mazhab pemikiran menjadi ciri khas totalitas pandangannya;

"Jika seseorang percaya pada mazhab pemikiran, maka kepercayaannya, emosi, jalan hidup, politik, pandangan-pandangan sosial, konsep-konsep intelektual, keagamaan dan etikanya tidak terpisah, melainkan saling berkaitan. Semuanya itu hidup dengan satu spirit, mewujud secara harmonis dalam satu bentuk....Karena dia memiliki mazhab pemikiran, maka keyakinan-keyakinan politik, ekonomi atau bahkan kesusasteraannya berjalan secara harmonis, 
selaras dan terpadu. Semuanya ini melahirkan suatu bentuk umum dan bentuk ini disebut "mazhab ideologi" (Ramadhan, 2011).

Dalam pandangannya, ideologi adalah fitrah yang paling penting dan bernilai serta merupakan kesadaran diri yang istimewa dalam diri manusia. Kesadaran ideologis merupakan kesadaran khusus yang khas bagi manusia tanpa terkecuali. Hal tersebut dikarenakan, ideologi menjadi "kebutuhan" yang paling mendasar bagi manusia untuk memberi arah atau petunjuk dalam mengungkap kebenaran sampai ke tingkat melakukan verifikasi atas tindakan masyarakat serta kondisi-kondisi sosial yang melingkupinya. Secara sederhana, ideologi berperan dalam pemberian cara pandang, membentuk pemahaman, serta mengarahkan prilaku manusia dalam berinteraksi dengan dunianya.

Pendapat Syari'ati tentang ideologi di sini berkebalikan dengan pandangan Marx dan Weber. Jika dalam pandangannya Marx dan Weber mengatakan bahwa ideologi dibentuk oleh struktur masyarakat, Syari'ati dengan pandangannya justru menyatakan bahwa, dengan kesadaran diri (ideologi) inilah manusia membentuk masyarakat. Ideologi menempati posisi yang begitu kuat dalam pikiran dan keyakinan manusia dan tetap diperpegangi sebagai penuntun hidup yang paripurna bagi para penganutnya. Sehingga benar kiranya jika kemudian Syari'ati beranggapan bahwa hanya ideologilah yang mampu merubah masyarakat karena sifat dan keharusan ideologi yang meliputi keyakinan, tanggung jawab, dan keterlibatan untuk komitmen. Dengan kata lain, dalam hal ini ideologi yang dimaksud oleh Syari'ati di sini sejalan dengan pandangan Antonio Gramsci yang mengatakan baha ideologi lebih sekedar sistem ide.

Secara historis Ideologi memiliki keabsahan yang bersifat psikologis (memberikan spirit perjuangan). Ideologi juga mengatur dan memberikan tempat bagi manusia untuk bergerak dan mendapatkan kesadaran mengenai 
posisi maupun perjuangan mereka dalam kehidupannya. Sebagaimana yang dikatakan oleh Syariati di atas bahwa ideologilah yang mampu mengubah masyarakat (Sabara, 2016: 221-222). Dan Islam harus beralih dari sekadar menjadi perumusan dokumen teknis yang tidak memiliki tujuan di tangan para teolog, menjadi kerangka kerja ideologis yang menggerakkan massa untuk bertindak (Miller, 1995: 404). Islam tidak sekedar aturan-aturan hidup bagi terseleggaranya sebuah pentas kehidupan yang harmonis. Namun ia merupakan darah yang menggerakkan seluruh organ kehidupan umat manusia di bawah bimbingan ketauhidan, yaitu Allah. Baginya, Islam merupakan satu-satunya ideologi yang akan menyelamatkan umat Muslim khususnya masyarakat Muslim Iran pada saat itu dari segala bentuk tekanan dan penindasan (Syari'ati, T.tp: 38).

Islam sebagai ideologi menurutnya bukanlah spesialisasi ilmiah, melainkan perasaan yang dimiliki seseorang berkenaan dengan madzhab pemikiran sebagai satu sistem keyakinan dan bukan sebagai satu kebudayaan. Ini berarti memahami Islam sebagai sebuah ide dan bukan sebagai sekumpulan ilmu, dan memahami Islam sebagai suatu gerakan kemanusiaan , historis, dan intelektual, bukan sebagai Gudang informasi teknis dan ilmiah. Dan akhirnya, ini juga berarti memandang Islam sebagai ideologi dalam pikiran seorang intelektual dan bukan sebagai ilmu-ilmu agama kuno dalam pikiran seorang ahli agama (Syari'ati, 1992: 18).

Untuk menjadikan Islam sebagai ideologi yang mampu dipraksiskan dalam kehidupan dan memberi implikasi yang positif bagi manusia. Syari'ati menyajikan tahapan-tahapan ideologi secara detail. Pertama, Syariati berangkat dari satu pertanyaan mendasar mengenai kedudukan manusia dalam berhubungan dengan Tuhan dan alam semesta. Maka untuk menjelaskannya, terlebih dahulu Syari'ati meletakkan pandangan dunia Tauhid sebagai pandangan dunia yang mendasar. Bagi Syari'ati, Tauhid tak sekedar pemahaman, lebih dari itu, Tauhid adalah ideologi pembebasan. 
Basis ideologi Syari'ati yang didasarkan pada Tauhid merupakan sebuah pandangan dunia mistik-filosofis yang memandang jagad raya sebagai sebuah organisme hidup tanpa dikotomisasi. Sebagaimana dinyatakan oleh Syari'ati sendiri bahwa Tauhid meninggalkan lingkaran diskusi, penafsiran, dan perdebatan filosofis, teologis, dan ilmiah, Tauhid masuk dalam urusan masyarakat. Di dalam Tauhid tercakup berbagai masalah yang menyangkut hubungan sosial (Sabara, 2016: 222).

Dengan demikian, Syariati kemudian sampai pada pemikiran tentang masyarakat yang ideal yang disebutnya sebagai ummah. Konsep Ummah disini sama halnya dengan masyarakat, rakyat, bangsa, dan sebagainya. Akan tetapi, ummah lebih memiliki bobot kejiwaan yang progressif dan lebih dinamis karena memiliki visi ideologi yang jelas. Kata "Ummah" mempunyai akar kata amm yang mempunyai makna keyakinan dengan maksud tertentu. Maka dari itu ummah adalah masyarakat dengan sejumlah individu yang memiliki keyakinan serta tujuan yang sama, yang secara bersama-sama dan secara harmonis bermaksud meningkatkan dan mencapai tujuan yang telah dirumuskan bersama. Dengan kata lain, masyarakat yang ideal adalah masyarakat yang memiliki sistem sosial yang mempunyai dasar persamaan dan keadilan, pemilikan oleh rakyat, serta munculnya sistem Habil, yakni sebuah masyarakat yang berdasarkan persamaan dan persaudaraan.

Landasan falsafah ummah disini bukan demokrasi menurut konsep Barat, bukan pula liberalisme yang cenderung kepada persaingan antara kekuatan sosial, bukan aristokrasi yang tidak merakyat, bukan pula kediktatoran maupun oligarki. Ummah yang ideal disini memerlukan kepemimpinan (imamah) yang bersih dan menaruh komitmen pada gerakan juga perkembangan masyarakat, kepemimpinan revolusioner yang mendasarkan perjuangannya pada pandangan atau teologi yang bertujuan merealisasikan kehendak Tuhan dalam kreasi kemanusiaan (Ramadhan, 2011). 
Sehingga dalam hal ini, kepemimpinan (imamab) dalam pandangan Syari'ati dapat digambarkan sebagai kepemimpinan progresif dan revolusioner yang bertentangan dengan rezim-rezim politik lainnya yang berfungsi untuk membimbing manusia serta membangun masyarakat di atas fondasi yang benar dan kuat, yang mengarahkannya menuju kesadaran, pertumbuhan, dan kemandirian dalam mengambil keputusan.

Jadi, imamah merupakan manifestasi dari "risalah kepemimpinan dan bimbingan individu dan masyarakat" dari "apa yang kini ada" (das sein) menuju "apa yang seharusnya ada (das sollen) semaksimal yang bisa dilakukan. Bukan berdasarkan pada keinginan pribadi seorang imam, melainkan atas dasar konsep yang baku yang menjadi kewajiban bagi imam lebih dari individu lainnya (Ikhya’udin, 2009: 79).

Syari'ati mengatakan bahwa sistem pemerintahan yang sejalan dengan Islam harus bertedensi sosial dengan menghapus sentralistik kekuasaan yang diwariskan secara turun-temurun. Dalam hal sentralistik kekuasaan ini, Syari'ati mempunyai pandangan yang berbeda dengan Imam Khomeini meskipun keduanya merupakan tokoh terpenting dalam pembebasan negara Iran dalam kungkungan kekuasaan Syah Pahlevi. Jika Imam Khomeini menempatkan kaum ulama sebagai otoritas tertinggi dalam bidang politik maupun agama, maka Syari'ati menolak dominasi politik kaum ulama, dan sebaliknya ia menempatkan kaum "intelektual yang tercerahkan” (rausanfikr), sebagai pemegang otoritas kekuasaan politik.

Menurutnya, kaum intelektual merupakan para eksponen real dari Islam yang "rasional" dan "dinamis", dan bahwa tugas utama mereka adalah untuk memperkenalkan suatu "pencerahan" dan "reformasi" Islam. Disinilah kemudian peran kaum intelektual Muslim untuk menghubungkan dirinya dengan massa, menentang kaum reaksioner dan membangkitkan Islam sebagai agama jihad yang menentang penindasan dan menegakkan keadilan. Ia berkeyakinan bahwa pemerintahan kaum intelektual merupakan satu- 
satunya pilihan yang bisa diterima dan diperlukan setelah revolusi sehingga dengan tegas Syari'ati menolak jika imamah diartikan sebagai pemberian kekuasaan yang besar kepada kaum ulama. Baginya, kaum ulama tidak berhak memonopoli kebenaran di bidang agama, karena para ulama sama sekali tidak bisa lepas tangan dari terciptanya kemunduran di dunia Islam pada saat itu (Suhaimi, 2012: 21).

\section{Skema Pemikiran Tauhid Dalam Konsep Religius Humanistik Ali Syari'ati}

Berikut ini adalah skema dari "sekolah pemikiran manusia" versus "keyakinan Islam" dalam diagram humanis Ali Syari'ati. Dasarnya adalah pandangan dunia dengan menempatkan ideologi yang dibagi menjadi filsafat, sejarah, dan sosiologi. Ali Syari'ati memposisikan humanisme di tengahtengah struktur ini, untuk menyoroti signifikansinya bagi pemikiran Barat. Tingkatan berikutnya adalah "Ciety Ideal" dan di puncak ilustrasi ini Ali Syari'ati memposisikan "the Ideal Man".

Dalam diagram kedua, "sistem kepercayaan Islam", dasarnya adalah tauhid, yang terdiri atas sejarah, manusia, masyarakat, dan dunia. Level selanjutnya adalah "Islam". Di sini Ali Syari'ati masuk ke deskripsi terperinci dari serangkaian hubungan dialektis dalam mengaitkan hubungan antara kelas sosial yang berbeda dari "yang dieksploitasi" dan "yang mengeksploitasi" atau antara roh, iblis, Tuhan, dan manusia. Mengikuti Islam, level berikutnya adalah umma yang terhubung dengan kategori "Islam" melalui Imma. Ummah diikuti oleh kategori kesadaran, kebebasan dan penciptaan yang dihubungkan melalui garis putus-putus ke puncak diagram: keberadaan 'Tuhan' (Machlis, 2014: 198-199). 


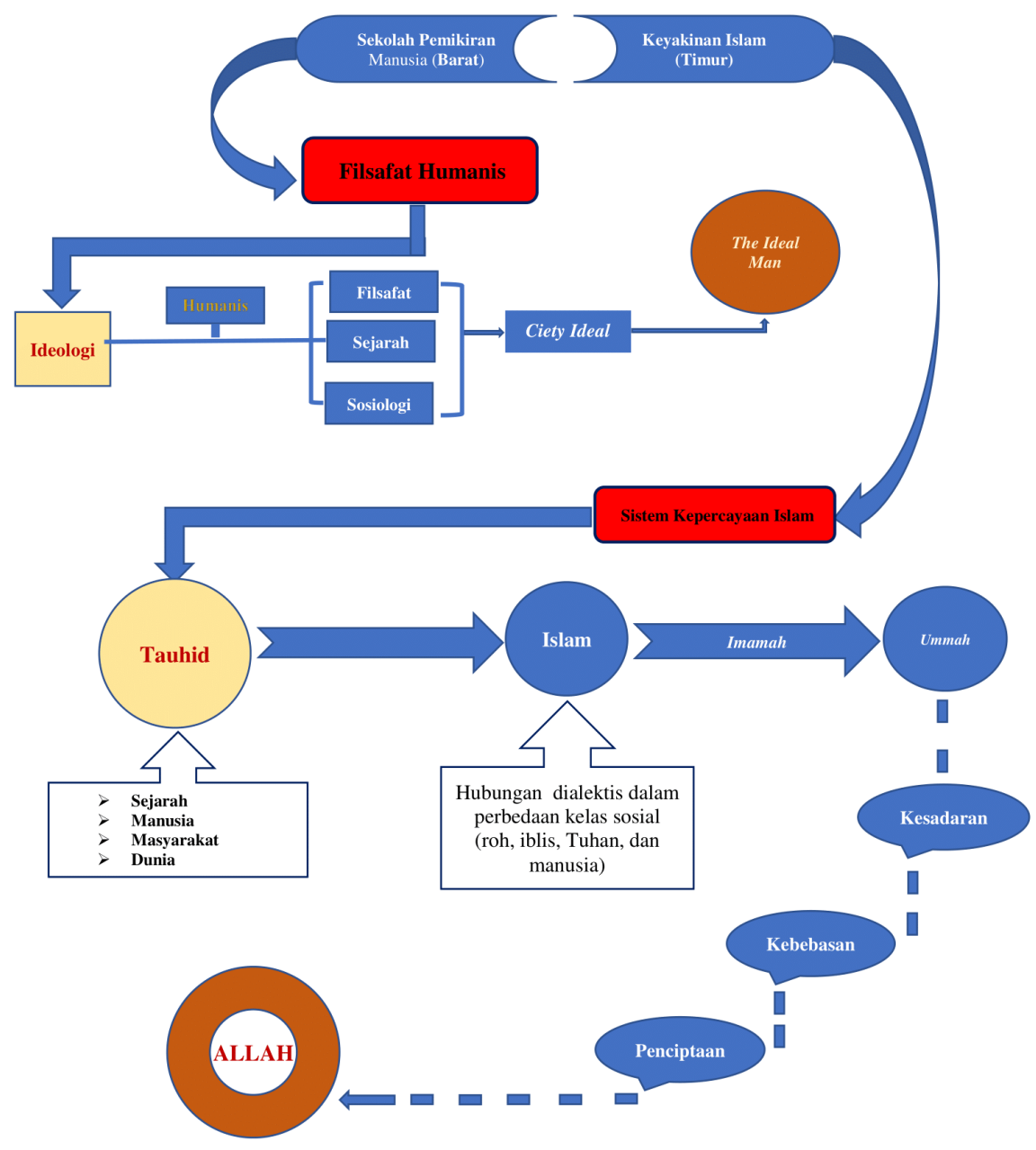

Pada intinya, tujuan ilustrasinya yang dua sisi adalah untuk membandingkan pandangan dunia Barat khususnya filsafat humanis dengan pandangan dunia tauhid. Di sini menunjukkan bahwa tujuan akhir dari pemikiran Barat adalah untuk menciptakan pria yang ideal. Manusia yang sempurna dalam konsep pemikiran Barat ini dikontraskan dalam sosok paralel Syari'ati dengan sistem kepercayaan Islam di mana tujuan utamanya adalah keberadaan Tuhan. 
Syari'ati sangat kritis terhadap humanisme. Filosofinya ini digambarkan dengan mengganti manusia materi yang hidup dengan manusia yang saleh, yang merupakan produk dari alam, masyarakat dan peradaban. Di sisi lain, dalam ilustrasi paralelnya tentang tauhid, tujuannya adalah untuk mencapai Tuhan, atau untuk memperoleh pengetahuan tentang Tuhan. Namun, Syari'ati menelusuri garis putus-putus di hadapan kata Tuhan, menandakan perjalanan manusia yang berkesinambungan menuju Tuhan, di mana ia tidak akan pernah sepenuhnya memahami keberadaan Yang Mahakuasa (Machlis, 2014: 198-199).

Ketergantungannya pada gagasan dualis dapat dihubungkan dengan ide-ide esksistensialis yang juga memiliki dasar yang jelas dalam Syiah. Menurut kepercayaan, dua ekstrem yang bermusuhan menentukan jalannya sejarah dalam pertempuran antara yang baik dan yang jahat, pengetahuan dan ketidaktahuan, diwakili oleh para imam dan pengikutnya di satu sisi dan musuh mereka di sisi lain. Meskipun konsep-konsep ini ada dalam Islam pada umumnya mereka menerima pemahaman unik dalam Syiah, di mana ini bukan hanya individu tetapi komponen dari dikotomi dasar yang membentuk terbentangnya sejarah.

Di dalam gagasan dualis ini, Syiah menggambarkan ketegangan internal antara dua tingkat realitas terdependen: manifes, semu dan eksoteris (dzahir) dari rahasia dan esoteris (batin). Gagasan biner ini yang ada juga pemikiran dimanifestasikan menurut pemikiran Syi'ah dalam sifat Tuhan, Imam, Nabi, dan bahkan dalam agama itu sendiri. Kaum Syiah juga menjunjung tinggi persepsi diri tentang keyakinan mereka. Dalam pemikiran klasik Syi'ah, kaum Syi'ah sendiri sebagai kelompok yang dipilih (at-khassa), yang memiliki Islam sejati (iman), sementara mayoritas Muslim adalah rakyat jelata atau generalitas umat Islam (al-'amma). Gagasan Ali Syari'ati tentang tauhid mencerminkan pengertian timbal balik antara elemen-elemen yang 
saling bertentangan yang membentuk totalitas integral agama (Machlis, 2014: 200-201).

Mengandalkan baik pada persepsi dualis Syiah klasik dan pada filsafat modern yang ada, Syari'ati mampu menciptakan hubungan yang lebih timbal balik antara Tuhan, manusia dan agama. Manusia sendiri adalah komponen tauhid. Dia diberi peran aktif dalam menerapkan nilai keadilan Allah, melalui tindakan manusia di masa kini. Bersamaan dengan itu Ali Syari'ati juga menekankan bahwa manusia pada akhirnya tidak dapat mencapai Yang Mahakuasa, dan persatuan agama tidak melibatkan panteisme, dualisme atau politeisme.

Tidak ada yang abadi, termasuk manusia sendiri. Meskipun ia memiliki kehidupan biologis dan spiritual. Dia terdiri dari lumpur hitam yang dibusuk, namun secara spiritual memiliki esensi Tuhan dan mewujudkan kehendak mutlak Tuhan. Dia memiliki keberadaan ganda: manusia di satu sisi rendah hati dan lemah dan di sisi lain kuat dan luar biasa. Memang rasa Syari'ati tentang dualisme, pilihan manusia dan aktivisme sosial memiliki konotasi eksistensialis yang jelas. Namun, ia juga merefleksikan ajaran tradisional muslim tentang subordinasi manusia kepada Sang Pencipta di mana kualitas-kualitas khusus manusia diperoleh melalui anugerah Allah semata. Meskipun ia mengandalkan kosa kata eksistensialis, tujuan utama Syari'ati adalah untuk mempromosikan kepercayaan pada ciptaan ilahi (Machlis, 2014: 1200-201).

\section{PENUTUP}

Ali Syariati merupakan seorang seorang intelektual sekaligus pemikir besar yang memicu energi intelektual untuk Revolusi Islam di Iran, dan menaruh perhatian lebih pada humanisme. Menurutnya, manusia adalah makhluk merdeka dan memiliki potensialitas tanpa batas untuk menentukan nasibnya sendiri dan bukan ditentukan oleh kekuatan eksternal dengan membangun semangat Tauhid dan menjadikan Islam sebagai ideologi yang 
mampu dipraksiskan dalam kehidupan dan memberi implikasi yang positif bagi manusia.

Gagasan yang ditawarkannya tentang dunia religius bumanistik untuk memerangi dualisme kelas antara kelas penguasa dan yang dikuasai, antara kelas borjuasi dan proletariat, sehingga manusia akan menemukan keesaan yang orisinil dalam rangka membangun kesadaran manusia pada misinya sebagai wakil atau khalifah Tuhan di muka bumi. Menurutnya, kehidupan adalah kesatuan dalam trinitas tiga hipotesis, yaitu Tuhan, manusia, dan alam yang dalam pandangan dunia tauhid adalah pandangan dunia yang melihat kenyataan sebagai realitas yang holistik, universal, integral dan monistik.

\section{DAFTAR PUSTAKA}

Abedi, Mehbi and Mehdi Abedi. (1986). Ali Shariati: The Architect of the 1979 Islamic Revolution of Iran, Taylor \& Francis. Iranian Studies, $19,(3 / 4)$.

Abrahamian, Ervand. (1982). 'Ali Shari'ati: Ideologue of the Iranian Revolution. MERIP Reports, 102, Islam and Politics.

Adhan, Syamsul Rijal. (2016). Theology Of Liberation In Thought Of Ali Shari'ati. Journal of Islam And Science, 3 (2).

Afrasiabi, K. L. (2000). An Islamic Utopian: A Political Biography of 'Ali Shari'ati by Ali Rahnema and 'Ali Shari'ati. Middle East Journal, 54 (1).

Ahmad, M. Kursani. (2011). Teologi Pembebasan dalam Islam: Telaah Pemikiran Asghar Ali Engineer. Ilmu Usbuluddin, 10 (1).

Akhavi, Shahrough. (1998). Islam, Politics and Society in the Thought of Ayatullah Khomeini, Ayatullah Taliqani and Ali Shariati. Middle Eastern Studies, 24 (4).

Bayat, Assef and تايب فصاً. (1990). Shari'ati and Marx: A Critique of an "Islamic" Critique of Marxism. Alif: Journal of Comparative Poetics, (10).

Cole, Juan R. I. (1984). Fatima Is Fatima by Ali Shariati and Laleh Bakhtiar; Man and Islam by Ali Shariati and Fatollah Marjani. Middle East Joumal, 38 (1).

Dabashi, Hamid. (1987). Man and Islam by Ali Shari'ati and Fatollah Marjani. Taylor \& Francis, Iranian Studies, 20 (1). 
Ikhya'udin, Imam. (2009). Konsep Imamah Menurut Ali Syariati. Skripsi, Fakultas Adab, UIN Sunan Kalijaga Yogyakarta.

Irdayanti, Andi. (2018). Relasi Negara dengan Ummah Menurut Ali Syariati dalam Prespektif Kebangsaan Indonesia. Skripsi, Fakultas Ushuluddin, Filsafat dan Politik, UIN Alauddin Makassar.

Machlis, Elisheva. (2014). Ali Shari'ati and the Notion of Tawhid: Reexploring the Question of God's Unity. Brill, Die Welt des Islams, 54 (2).

Miller, Michael. (1995). Religion and Revolution in the Modern World: Ali Shari'ati's Islam and Persian Revolution by Naghi Yousefi. Sir Artbur Lewis Institute of Social and Economic Studies, 44 (2/3).

Nugroho, Anjar. (2017). Ali Shari'ati's Revolutionary Islamic Thought And Its Relevance To The Contemporary Socio-Political Transformation. Indonesian Journal of Islam and Muslim Societies, 7 (2).

Nugroho, Anjar. (2014). Pengaruh Pemikiran Islam Revolusioner Ali Syari'ati Terhadap Revolusi Iran. Profetika, Jurnal Studi Islam, 15 (2).

Nurrochman. (2014). Islam dan Sosialisme; Telaah atas Pemikiran Ali Syari'ati. Wabana Akademika, 1 (1).

Ramadhan, M. (2011). Teologi Kemanusiaan Studi atas Pemikiran Ali Syariati. Teologia $22(20$.

Suhaimi, El. (2012). Pemerintahan Islam Menurut Ali Syari'ati. Tesis, Institut Agama Islam Negeri Sumatera Utara Medan.

Sabara. (2016). Pemikiran Teologi Pembebasan Ali Syari'ati. Al-Fikr, 20 (2).

Saleh M, Marhaeni. (2018). Ali Syari’ati; Pemikiran dan Gagasannya. Jurnal Aqidah-Ta, 4 (2).

Sari, Zamah. (2018). Relevansi Pemikiran Sosiologi Islam Ali Syariati Dengan Problematika Pendidikan Islam di Indonesia. Ta'dibuna, 7 (2).

Supriyadi, Eko. (2010). Sosialisme Islam: Pemikiran Ali Syariati. Yogyakarta: Rausyan Fikr Institute.

Syari'ati, Ali. (1992). Islam Mað̧ab Pemikiran dan Aksi (M.S. Nasrulloh dan Afif Muhammad, Penerjemah.). Bandung: Mizan.

Syari'ati, Ali. Ali Syariati: Melawan Hegemoni Barat, Ed. M. Deden Ridwan, (Yogyakarta: Rausyan Fikr Institute, T.tp.).

Syari'ati, Ali. (2011). Do'a, Tangisan, \& Perlawanan Refleksi Sosialisme Religius: Do'a Ablulbait dan Asyura di Karbala (Ening Budi Nugraha dan Arum 
Rindu Sekar Kasih, Penerjemah.). Yogyakarta: Rausyan Fikr Institute.

Syari'ati, Ali. (2017). Sejarah Masa Depan (Tabi Dasan, Penerjemah.). Karkasa.

Tobroni, Faiq. (2015). Pemikiran Ali Syari'ati dalam Sosiologi (Dari Teologi Menuju Revolusi). Sosiologi Reflektif, 10 (1).

Vakily, Abdollah. (1991). Ali Shariati And The Mystical Tradition Of Islam. Thesis, The Faculty Of Graduate Studies And Research, Mcgill University, Montreal. 